\title{
DEVELOPMENT OF UNDERGROWTH PHENOLOGICAL SPRUCE FORMS IN DIFFERENT SPECIES COMPOSITION OF FOREST STANDS
}

\author{
Natalia Belyaeva ${ }^{1}$, Dmitry Danilov ${ }^{1,2}$ \\ ${ }^{1}$ Saint-Petersburg State Forest Technical University named after S.M. Kirov, Russia \\ ${ }^{2}$ Leningrad Scientific Research Institute of Agriculture "BELOGORKA", Russia \\ galbel06@mail.ru; stown200@mail.ru
}

\begin{abstract}
The aim of research was to determine peculiarities of relations between mature layer of the stand with distribution of spruce (Picea abies. Kr.) regeneration according phenology forms and growth specifics.

The study examined the success of the resumption of spruce in the Leningrad region under the canopy of the parent stand. In stands with different share of spruce and in various forest-typological conditions, the features of the relationship between the maternal canopy of the stand, the distribution of the natural resumption of spruce by phenological forms and its course of growth were investigated. The account of the undergrowth was carried out by two methods: continuous reading and selective-statistical method.

Regardless of the state of viability of spruce undergrowth, the increase in success of regeneration goes from a late vegetation season growth start form to an early one. Under the canopy of the maternal tree stand, young spruce of the early form has the best growth and development indices. In general, under the canopy of spruce stands, the annual height increment in spruce undergrowth, regardless of the phenological structure, the size categories and the state of viability, is greater than under the canopy of pine, pine-spruce and birch-spruce stands. The best characteristics of spruce undergrowth, regardless of phenological forms in vaccinio-myrtillo-pinetum type of forest. When analyzing the characteristics of spruce undergrowth under the canopy of the stand, taking into account the phenological and altitudinal structure, and the state of viability, it was revealed that at the average age prevailing in the spruce undergrowth of the transitional form, the best parameters of growth have small and medium forms and growth in the early form.

Analyzing the characteristics of spruce undergrowth under the canopy of the stand, taking into account the phenological and height structure, as well as vitality status, it was revealed that at average age, dominating for the spruce undergrowth of transitional form, the best parameters of small and medium groups of undergrowth has early vegetation season growth start form. The best parameters of the growth have a large group of undergrowth of late vegetation season growth start form.
\end{abstract}

Key words: young growth of spruce, phenological forms, the composition of the stand.

\section{Introduction}

There are many morphologic, phenological and other forms of spruce (Münch, 1923; Barton, 1988; Holzer \& Schultze, 1988; Rohmeder, 1952; 1963; Akakiev, 1960; Ronis \& Veveris, 1964; Martynov et al., 1994). The singling out of these forms is essential to forestry and selection (Alekseev, 1974; Kharitonov, 1937; Golikov, 2007). Spruce has three phenological forms: early start of vegetation season, transitional and late start of vegetation season. The basic difference among them lies in start dates of vegetation. In its turn, the economic value of singling out the phenological forms is associated with differences in the rapidity of their growth and in the length of vegetation period. For some authors, the phenological structure of spruce undergrowth is genetically conditioned (Golikov, 2007; Popov et al., 1985). According to others, the phenological structure of spruce undergrowth is influenced by environmental conditions: the degree of luminance, thermal regime, growing season length, site class and others (Tarkhanov \& Shchekalev, 2007; Krasnobaeva, 2013; Belyaeva, 2013). Some researchers believe that the average height increment in different phenological forms is the same. Some have arrived at a conclusion that spruces coming out early have a greater increment in height than spruces coming out late (Milyutin, 1963; Milenin \& Arbuzov, 2011; Makarov \& Druzhinin, 2013). Acknowledgement of the fact that phenological forms of spruce growing differently can be found in a research work by V.Ya. Popov et al. (1985), P.G. Melnik and S.M. Savistin (1995) take the view that the growth course of spruce's different phenological forms depends largely on weather conditions in a specific year. A.M. Paltsev (1986) came to similar results when considering geocultures of spruce. S.N. Tarkhanov (2007) reported on the different growth of phenological forms of fir spruce in individual years. It is also reported on differences in productivity of various phenological forms of spruce in its different distribution areas (Ronis \& Veveris, 1964; Melnik \& Savostin, 1995; Krasnobaeva, 2013). Summing up the above, it is to be noted that the influence of mother stand upon the growth course of spruce undergrowth having different phenological forms is underinvestigated.

The purpose of this paper was to expose peculiarities of interconnections among the mother 
stand's canopy, the distribution of spruce's natural regeneration by phenological forms and the growth course under conditions of the Leningrad region.

\section{Materials and Methods}

The natural regeneration of fir spruce under the forest canopy was registered within the territory of Siversky Les experimental forestry enterprise in the Karashevsky, Orlinsky, Druzhnoselsky and Ontsevky forest districts of the Gatchina forest division in the Leningrad region (59 $34^{\prime} 35^{\prime \prime}$ ' $\left(59^{\circ} 34^{\prime}\right.$, 58) N\&30 $7^{\prime} 41^{\prime \prime}\left(30^{\circ} 7^{\prime} 69\right)$ E) on the permanent sample plots ranging in size from 0.25 to 0.5 ha.

Methods of singling out the phenological forms of fir spruce differ with different researchers. In our research we made use of techniques proposed by A.V. Gryazkin (1997). As an early form, we designated spruce biotypes whose terminal bud starts breaking prior to the efflorescing of European bird cherry. As a late form, we designated spruce biotypes whose terminal bud starts breaking after the efflorescing of European mountain ash or after the beginning of Scotch pine's pollen dispersion under conditions of the Leningrad region, with the transitional form being in-between these two forms.

From 600 to 3000 of spruce undergrowth trees per ha were counted on the sample plots. Phenological signs of spruce's young generation were investigated in thick stands of spruce trees, pine trees and birch trees in a pleurocarpous moss group of forest types. The natural regeneration of fir spruce was registered in the spring 2011, 2014 and 2015 under the canopy of stands. This registration was carried out by two methods: a complete enumeration approach and a statistical sampling method. Use was made of research techniques presented in depth in the paper by A.V. Gryazkin and N.V. Belyaeva (2013). The age of undergrowth was determined according to the annual increment of branches for each example of spruce undergrowth and was calculated as an average from total amount of undergrowth. The complete enumeration was carried out on bands, $5 \mathrm{~m}$ wide, divided into squares $5 \times 5 \mathrm{~m}$. The registration by statistical sampling method was carried out on circular plots, $10 \mathrm{~m}^{2}$ each, established at equidistance from each other in free running.

\section{Results and Discussion}

In previous investigations, regenerative processes of spruce were researched in homogenous spruce stands (Ronis \& Veveris, 1964; Gryazkin \& Belyaeva, 2013). Influence of mature layer of mixed stand on regeneration of new generation of spruce was not studied. Under the stand canopy in forest types being investigated, the spruce undergrowth of early form has got better indices of growth and development (see Table 1). When comparing basic characteristics of spruce undergrowth by its phenological forms, it is evident that the specimens of early form, which are of about the same age (with a difference of no more than two years), have a greater height. The average height of the spruce undergrowth of an early form is one and a half as much as that of the spruce undergrowth of a late form. The average increment in the spruce undergrowth of an early form is 1.5 to $2 \mathrm{~cm}$ above the average increment in the spruce undergrowth of transitional and late forms. It is being noted that, under the canopy of spruce stands, the spruce undergrowth of an early form has the best parameters of growth and development (see Table 1), with its average increment being 3 to $4 \mathrm{~cm}$ greater than that of the spruce undergrowth of transitional and late forms. Under the canopy of pine stands, the best indices are with the spruce undergrowth of a transitional form, with its average increment being 1 to $3 \mathrm{~cm}$ greater than that of the spruce undergrowth of early and late forms. Under the canopy of pine-spruce and spruce-birch stands, all the forms of spruce undergrowth have approximately the same indices in terms of average increment.

In general, under the canopy of pine and spruce stands, the indices of the spruce undergrowth, independently of its phenological structure, are higher than those under the canopy of pine-spruce and spruce-birch stands. The average increment is 3 to 7 $\mathrm{cm}$ greater in the spruce undergrowth growing under the canopy of pine and spruce stands.

While analyzing characteristics of spruce undergrowth with different phenological forms versus a relative density of the stand, its age, and growing stock, it was revealed that, with an increase in phenological forms, the indices of spruce undergrowth go down without regard to its phenological structure (see Table 1). An average increment of spruce undergrowth decreases by a factor of 2 to 4 with an increase in relative density of the stand, its age, and growing stock. This suggests that there is a close relationship among the composition of mother stand and the degree of luminance under it as well as the growth course of spruce undergrowth of different phenological forms.

It was further noted that the vaccinium forest type has the best characteristics of spruce undergrowth irrespective of its phenological forms (see Table 1).

It was revealed that, with a comprehensive tending of forest, an average increment of spruce undergrowth of different phenological forms decreases by a factor of 1.5 to 2 (see Table 2), which can be explained by the fact that the application of fertilizers improves the nutritional conditions for the grass layer and nether vert. resulting in an extreme competition. 
Table 1

Character of spruce undergrowth with different phenological forms

\begin{tabular}{|c|c|c|c|c|}
\hline Dominant species & Stand composition & $\begin{array}{c}\text { Height } \\
\left(\mathrm{H}_{\mathrm{av}}\right), \mathrm{cm}\end{array}$ & $\begin{array}{c}\text { Age } \\
\left(\mathrm{A}_{\mathrm{av}}\right) \text {, years }\end{array}$ & $\begin{array}{c}\text { Increment } \\
\left(\mathrm{Z}_{\mathrm{av}}\right), \mathrm{cm}^{-1} \text { year }^{-1}\end{array}$ \\
\hline \multicolumn{5}{|c|}{ Early coming-out phenological form } \\
\hline \multirow{10}{*}{ Spruce } & 9S1P & 52.1 & 12.9 & 4.0 \\
\hline & 9S1P & 123.8 & 17.7 & 7.0 \\
\hline & $8 \mathrm{~S} 2 \mathrm{P}$ & 69.5 & 13.7 & 5.1 \\
\hline & $10 \mathrm{~S}+\mathrm{P}$ & 117.0 & 23.0 & 5.0 \\
\hline & $8,7 \mathrm{~S} 1,1 \mathrm{P} 0,1 \mathrm{~B} 0,1 \mathrm{As}$ & 114.7 & 12.7 & 9.0 \\
\hline & 6,5S3,1P0,3As0,1B & 66.3 & 11.9 & 5.6 \\
\hline & 9,1S0,9B+Al & 176.4 & 9.4 & 18.7 \\
\hline & 7,8S1,6P0,6B & 147.3 & 12.6 & 11.7 \\
\hline & 6,6S3,2P0,2B & 164.2 & 10.3 & 15.9 \\
\hline & Average & 132.0 & 13.7 & 10.5 \\
\hline \multirow{7}{*}{ Pine } & $10 \mathrm{P}$ & 134.4 & 11.4 & 11.8 \\
\hline & $10 \mathrm{P}$ & 203.7 & 20.5 & 9.9 \\
\hline & $10 \mathrm{P}$ & 170.0 & 12.5 & 13.6 \\
\hline & 7,8P1,3S0,9B & 158.5 & 23.8 & 6.7 \\
\hline & 5P2S2B1As & 92.1 & 22.1 & 4.2 \\
\hline & 6P2S2B & 119.5 & 21.3 & 5.6 \\
\hline & Average & 146.4 & 18.6 & 8.6 \\
\hline \multirow{7}{*}{ Pine + Spruce } & I 10P / II 9S1B & 99.9 & 23.4 & 4.3 \\
\hline & I 10P / II 5S5B & 140.6 & 14.6 & 9.6 \\
\hline & 4,9S4,1P0,8As0,2B & 56.2 & 23.5 & 2.4 \\
\hline & $5,4 \mathrm{~S} 4,2 \mathrm{P} 0,4 \mathrm{As}+\mathrm{B}$ & 65.2 & 13.2 & 4.9 \\
\hline & I 10P / II 7S2B1As & 105.3 & 22.0 & 4.8 \\
\hline & 4P $4 \mathrm{~S} 2 \mathrm{~B}$ & 80.8 & 14.4 & 5.6 \\
\hline & Average & 91.3 & 18.5 & 5.3 \\
\hline \multirow{2}{*}{ Spruce + Birch } & I 10B+As+P / II 10S & 87.9 & 23.8 & 3.7 \\
\hline & Average & 87.9 & 23.8 & 3.7 \\
\hline \multicolumn{2}{|c|}{ Average across all sampling areas } & 123.2 & 16.7 & 8.4 \\
\hline \multicolumn{5}{|c|}{ Transitional phenological form } \\
\hline \multirow{7}{*}{ Spruce } & 9S1P & 40.7 & 10.7 & 3.8 \\
\hline & 9S1P & 84.3 & 14.2 & 5.9 \\
\hline & $8 \mathrm{~S} 2 \mathrm{P}$ & 76.0 & 15.2 & 5.0 \\
\hline & $10 \mathrm{~S}+\mathrm{P}$ & 116.0 & 32.4 & 3.6 \\
\hline & 8,7S1,1P0,1B0,1AS & 104.5 & 12.9 & 8.1 \\
\hline & 6,5S3,1P0,3AS0,1B & 49.7 & 9.6 & 5.2 \\
\hline & Average & 82.4 & 14.8 & 6.3 \\
\hline \multirow{7}{*}{ Pine } & $10 \mathrm{P}$ & 257.0 & 19.4 & 13.2 \\
\hline & $10 \mathrm{P}$ & 233.5 & 22.5 & 10.4 \\
\hline & $10 \mathrm{P}$ & 210.0 & 13.0 & r6.2 \\
\hline & 7,8P1,3S0,9B & 129.7 & 18.4 & 7.0 \\
\hline & 5P2S2B1AS & 131.2 & 24.8 & 5.3 \\
\hline & 6P2S2B & 112.8 & 17.9 & 6.3 \\
\hline & Average & 179.0 & 19.3 & 9.7 \\
\hline \multirow{7}{*}{ Pine + Spruce } & I 10P / II 9S1B & 122.0 & 21.8 & 5.6 \\
\hline & I 10P / II 5S5B & 189.2 & 16.1 & 11.7 \\
\hline & 4,9S4,1P0,8AS0,2B & 31.2 & 15.3 & 2.0 \\
\hline & $5,4 \mathrm{~S} 4,2 \mathrm{P} 0,4 \mathrm{AS}+\mathrm{B}$ & 46.1 & 11.3 & 4.1 \\
\hline & I 10P / II 7S2B1AS & 107.6 & 22.7 & 4.7 \\
\hline & 4P4S2B & 36.2 & 8.2 & 4.4 \\
\hline & Average & 88.7 & 15.9 & 5.4 \\
\hline
\end{tabular}




\begin{tabular}{|c|c|c|c|c|}
\hline Dominant species & Stand composition & $\begin{array}{l}\text { Height } \\
\left(\mathrm{H}_{\mathrm{av}}\right), \mathrm{cm}\end{array}$ & $\begin{array}{c}\text { Age } \\
\left(\mathrm{A}_{\mathrm{av}}\right) \text {, years }\end{array}$ & $\begin{array}{c}\text { Increment } \\
\left(\mathrm{Z}_{\mathrm{av}}\right), \mathrm{cm}^{-1} \text { year }^{-1}\end{array}$ \\
\hline \multirow{2}{*}{ Spruce + Birch } & $\mathrm{I} 10 \mathrm{~B}+\mathrm{AS}+\mathrm{P} / \mathrm{II} 10 \mathrm{~S}$ & 116.8 & 32.0 & 3.6 \\
\hline & Average & 116.8 & 32.0 & 3.6 \\
\hline \multicolumn{2}{|c|}{ Average across all sampling areas } & 115.0 & 17.3 & 6.9 \\
\hline \multicolumn{5}{|c|}{ Late coming-out phenological form } \\
\hline \multirow{10}{*}{ Spruce } & 9S1P & 40.7 & 11.9 & 3.4 \\
\hline & 9S1P & 49.9 & 8.1 & 6.2 \\
\hline & $8 \mathrm{~S} 2 \mathrm{P}$ & 47.4 & 13.1 & 3.6 \\
\hline & $10 \mathrm{~S}+\mathrm{P}$ & 40.4 & 13.2 & 3.1 \\
\hline & 8,7S1,1P0,1B0,1AS & 56.7 & 8.9 & 6.4 \\
\hline & 6,5S3,1P0,3AS0,1B & 45.0 & 9.5 & 4.8 \\
\hline & 9,1S0,9B+AL & 100.0 & 8.1 & 12.4 \\
\hline & 7,8S1,6P0,6B & 101.0 & 10.1 & 10.0 \\
\hline & 6,6S3,2P0,2B & 81.8 & 9.1 & 9.0 \\
\hline & Average & 71.7 & 10.2 & 7.5 \\
\hline \multirow{7}{*}{ Pine } & $10 \mathrm{P}$ & 113.0 & 16.5 & 6.8 \\
\hline & $10 \mathrm{P}$ & 164.0 & 22.0 & 7.5 \\
\hline & $10 \mathrm{P}$ & 188.7 & 14.0 & 13.5 \\
\hline & 7,8P1,3S0,9B & 81.4 & 16.3 & 5.0 \\
\hline & 5P2S2B1AS & 101.0 & 30.8 & 3.2 \\
\hline & 6P2S2B & 56.3 & 15.3 & 3.7 \\
\hline & Average & 117.4 & 19.2 & 6.6 \\
\hline \multirow{7}{*}{ Pine + Spruce } & I 10P / II 9S1B & 108.4 & 21.4 & 5.1 \\
\hline & I 10P / II 5S5B & 103.7 & 15.8 & 6.6 \\
\hline & 4,9S4,1P0,8AS0,2B & 30.7 & 13.9 & 2.2 \\
\hline & $5,4 \mathrm{~S} 4,2 \mathrm{P} 0,4 \mathrm{AS}+\mathrm{B}$ & 40.9 & 11.3 & 3.6 \\
\hline & I 10P / II 7S2B1AS & 79.1 & 19.2 & 4.1 \\
\hline & 4P4S2B & 57.1 & 12.8 & 4.6 \\
\hline & Average & 70.0 & 15.7 & 4.4 \\
\hline \multirow{2}{*}{ Spruce + Birch } & I 10B+AS+P / II 10S & 98.1 & 30.3 & 3.2 \\
\hline & Average & 98.1 & 30.3 & 3.2 \\
\hline \multicolumn{2}{|c|}{ Average across all sampling areas } & 84.3 & 14.8 & 6.3 \\
\hline
\end{tabular}

Note: "P" - pine; "S" - spruce; "B" - birch; "AS" - aspen; "AL" - alder; "I" - first level of the stand; "II" - second level of the stand.

When comparing phenological forms of spruce undergrowth according to its state, it is evident that, on the whole, the spruce undergrowth of early form, both viable and unviable, has better parameters under the canopy of stands (see Table 2). An increase in these indices goes from the late phenological form to the early one, irrespective of the state of viability. The average height of spruce undergrowth of an early form is twice as much as that of spruce undergrowth of a late form. The average increment of viable spruce undergrowth of early form exceeds the average increment of spruce undergrowth of transitional and late forms by $20-30 \%$ and the average increment of inviable spruce undergrowth by $30-35 \%$. The undergrowth of an early form is 2 to 3.5 years older than the undergrowth of transitional and late forms. It was revealed that the canopy of spruce and sprucebirch stands provides better indices in terms of an average increment to the spruce undergrowth of an early form, while the canopy of pine and pine-spruce stands provides such indices to the spruce undergrowth of a transitional form.

Factor ANOVA analysis of influence of tree species composition on the number of undergrowth trees determines the undergrowth amount at the level $24 \%$ from the sum of all factors $(\mathrm{Ft}=3.0 \quad(\mathrm{p}=5 \%)$ and $F f=3.9$ ). The influence of pure pine stand on the amount of spruce undergrowth was not proved by statistics. But conducted ANOVA analysis of influence of layer factor of pine-spruce stand on the amount of spruce regeneration more than $30 \%$ from the sum of all factor influencing on this parameter.

As a whole, under the canopy of spruce stands, an average annual increment in height in the spruce undergrowth, irrespective of its phenological structure and category of size, is greater than that under the canopy of pine, pine-spruce and birch-spruce stands. Irrespective of the phenological structure and category of size, the spruce undergrowth is older under the canopy of birch-spruce stands. 
Table 2

\section{Character of spruce undergrowth with different phenological forms according to its state}

\begin{tabular}{|c|c|c|c|c|c|c|c|}
\hline \multirow[b]{2}{*}{$\begin{array}{l}\text { Dominant } \\
\text { species }\end{array}$} & \multirow[b]{2}{*}{$\begin{array}{c}\text { Number } \\
\text { of sampling area }\end{array}$} & \multicolumn{3}{|c|}{ Viable } & \multicolumn{3}{|c|}{ Inviable } \\
\hline & & $\begin{array}{l}\text { Height } \\
\left(\mathrm{H}_{\mathrm{av}}\right), \mathrm{cm}\end{array}$ & $\begin{array}{l}\text { Age } \\
\left(\mathrm{A}_{\mathrm{av}}\right) \text {, } \\
\text { years }\end{array}$ & $\begin{array}{c}\text { Increment } \\
\left(\mathrm{Z}_{\mathrm{av}}\right), \mathrm{cm} \\
\text { year }^{-1}\end{array}$ & $\begin{array}{l}\text { Height } \\
\left(\mathrm{H}_{\mathrm{av}}\right), \\
\mathrm{cm}\end{array}$ & $\begin{array}{l}\text { Age } \\
\left(A_{a v}\right) \text {, } \\
\text { years }\end{array}$ & $\begin{array}{c}\text { Increment } \\
\left(Z_{\text {av }}\right), \mathrm{cm}^{-1} \\
\text { year }^{-1}\end{array}$ \\
\hline \multicolumn{8}{|c|}{ Early coming-out phenological form } \\
\hline \multirow{10}{*}{ Spruce } & 9S1P & 50.7 & 12.5 & 4.1 & 63.3 & 16.2 & 3.9 \\
\hline & 9S1P & 320.0 & 44.0 & 7.3 & 84.6 & 12.4 & 6.8 \\
\hline & $8 \mathrm{~S} 2 \mathrm{P}$ & 68.7 & 13.8 & 5.0 & 73 & 13.3 & 5.5 \\
\hline & $10 \mathrm{~S}+\mathrm{P}$ & 117.0 & 23.0 & 5.0 & - & - & - \\
\hline & 8,7S1,1P0,1B0,1AS & 120.9 & 14.4 & 8.4 & 93.0 & 7.0 & 13.3 \\
\hline & 6,5S3,1P0,3AS0,1B & 87.8 & 13.1 & 6.7 & 57.0 & 11.4 & 5.0 \\
\hline & $9,1 \mathrm{~S} 0,9 \mathrm{~B}+\mathrm{AL}$ & 180.0 & 9.4 & 19.1 & 123.3 & 9.5 & 12.9 \\
\hline & 7,8S1,6P0,6B & 147.9 & 12.5 & 11.8 & 140.8 & 13.4 & 10.5 \\
\hline & 6,6S3,2P0,2B & 162.6 & 10.2 & 15.9 & 191.0 & 12.5 & 15.3 \\
\hline & Average & 154.4 & 16.5 & 10.7 & 103.3 & 12.0 & 9.2 \\
\hline \multirow{7}{*}{ Pine } & $10 \mathrm{P}$ & 161.0 & 13.0 & 12.4 & 28.0 & 5.0 & 5.6 \\
\hline & $10 \mathrm{P}$ & 203.7 & 20.5 & 9.9 & - & - & - \\
\hline & $10 \mathrm{P}$ & 170.0 & 12.5 & 13.6 & - & - & - \\
\hline & 7,8P1,3S0,9B & 189.7 & 27.0 & 7.0 & 65.0 & 14.0 & 4.6 \\
\hline & 5P2S2B1AS & 71.2 & 18.3 & 3.9 & 106.1 & 24.6 & 4.3 \\
\hline & 6P2S2B & 77.8 & 17.3 & 4.5 & 150.8 & 24.3 & 6.2 \\
\hline & Average & 145.6 & 18.1 & 8.6 & 87.5 & 17.0 & 5.2 \\
\hline \multirow{7}{*}{ Pine+ Spruce } & I 10P / II 9S1B & 113.7 & 21.3 & 5.3 & 89.5 & 25.0 & 3.6 \\
\hline & I 10P / II 5S5B & 155.0 & 24.5 & 6.3 & 131.0 & 8.0 & 16.4 \\
\hline & 4,9S4,1P0,8AS0,2B & 52.4 & 21.6 & 2.4 & 77.5 & 34.0 & 2.3 \\
\hline & 5,4S4,2P0,4AS+B & 62.5 & 12.5 & 5.0 & 69.0 & 14.2 & 4.9 \\
\hline & I 10P / II 7S2B1AS & 78.7 & 19.3 & 4.1 & 185.0 & 30.0 & 6.2 \\
\hline & 4P4S2B & 70.2 & 13.3 & 5.3 & 93.8 & 15.8 & 5.9 \\
\hline & Average & 88.8 & 18.8 & 4.7 & 107.6 & 21.2 & 6.6 \\
\hline \multirow{2}{*}{$\begin{array}{c}\text { Spruce + } \\
\text { Birch }\end{array}$} & $\mathrm{I} 10 \mathrm{~B}+\mathrm{AS}+\mathrm{P} / \mathrm{II} 10 \mathrm{~S}$ & 96.0 & 24.0 & 4.0 & 56.9 & 22.1 & 2.6 \\
\hline & Average & 96.0 & 24.0 & 4.0 & 56.9 & 22.1 & 2.6 \\
\hline \multicolumn{2}{|c|}{ Average across all sampling areas } & 132.4 & 17.8 & 8.3 & 98.9 & 16.5 & 7.1 \\
\hline \multicolumn{8}{|c|}{ Transitional phenological form } \\
\hline \multirow{7}{*}{ Spruce } & 9S1P & 40.5 & 10.6 & 3.8 & 44.0 & 13.5 & 3.3 \\
\hline & 9S1P & 97.5 & 15.3 & 6.4 & 73.6 & 13.3 & 5.5 \\
\hline & $8 \mathrm{~S} 2 \mathrm{P}$ & 76.4 & 14.7 & 5.2 & 75.2 & 14.8 & 5.1 \\
\hline & $10 \mathrm{~S}+\mathrm{P}$ & 82.7 & 23.7 & 3.5 & 166.0 & 45.5 & 3.7 \\
\hline & 8,7S1,1P0,1B0,1AS & 107.5 & 13.4 & 8.0 & 83.2 & 9.9 & 8.4 \\
\hline & 6,5S3,1P0,3AS0,1B & 59.4 & 9.2 & 6.5 & 45.6 & 9.8 & 4.7 \\
\hline & Average & 81.4 & 13.6 & 6.6 & 81.3 & 17.8 & 5.1 \\
\hline \multirow{7}{*}{ Pine } & $10 \mathrm{P}$ & 274.4 & 19.9 & 13.8 & 100.0 & 15.0 & 6.7 \\
\hline & $10 \mathrm{P}$ & 233.5 & 22.5 & 10.4 & - & - & - \\
\hline & $10 \mathrm{P}$ & 230.0 & 12.6 & 18.3 & 110.0 & 15.0 & 7.3 \\
\hline & 7,8P1,3S0,9B & 132.1 & 18.5 & 7.1 & 124.0 & 18.3 & 6.8 \\
\hline & 5P2S2B1AS & 57.0 & 17.0 & 3.4 & 152.4 & 27.0 & 5.6 \\
\hline & 6P2S2B & 47.9 & 13.6 & 3.5 & 183.0 & 22.6 & 8.1 \\
\hline & Average & 162.5 & 17.4 & 9.4 & 133.9 & 19.6 & 6.9 \\
\hline
\end{tabular}




\begin{tabular}{|c|c|c|c|c|c|c|c|}
\hline \multirow[b]{2}{*}{$\begin{array}{l}\text { Dominant } \\
\text { species }\end{array}$} & \multirow[b]{2}{*}{$\begin{array}{c}\text { Number } \\
\text { of sampling area }\end{array}$} & \multicolumn{3}{|c|}{ Viable } & \multicolumn{3}{|c|}{ Inviable } \\
\hline & & $\begin{array}{l}\text { Height } \\
\left(\mathrm{H}_{\mathrm{av}}\right), \mathrm{cm}\end{array}$ & $\begin{array}{l}\text { Age } \\
\left(\mathrm{A}_{\mathrm{av}}\right) \text {, } \\
\text { years }\end{array}$ & $\begin{array}{l}\text { Increment } \\
\left(\mathrm{Z}_{\mathrm{av}}\right), \mathrm{cm} \\
\text { year }{ }^{-1}\end{array}$ & $\begin{array}{c}\text { Height } \\
\left(\mathrm{H}_{\mathrm{av}}\right), \\
\mathrm{cm}\end{array}$ & $\begin{array}{l}\text { Age } \\
\left(\mathrm{A}_{\mathrm{av}} \cdot\right) \text {, } \\
\text { years }\end{array}$ & $\begin{array}{c}\text { Increment } \\
\left(\mathrm{Z}_{\mathrm{av}}\right)^{\circ}, \mathrm{cm} \\
\text { year-1 }\end{array}$ \\
\hline \multirow{7}{*}{ Pine + Spruce } & I 10P / II 9S1B & 143.6 & 22.3 & 6.4 & 93.1 & 21.2 & 4.4 \\
\hline & I 10P / II 5S5B & 246.8 & 19.4 & 12.7 & 65.7 & 9.1 & 7.2 \\
\hline & 4,9S4,1P0,8AS0,2B & 31.2 & 15.3 & 2.0 & - & - & - \\
\hline & $5,4 \mathrm{~S} 4,2 \mathrm{P} 0,4 \mathrm{AS}+\mathrm{B}$ & 44.0 & 10.5 & 4.2 & 49.2 & 12.5 & 3.9 \\
\hline & I 10P / II 7S2B1AS & 114 & 22.7 & 5.0 & 91.2 & 22.9 & 4.0 \\
\hline & 4P4S2B & 19.6 & 5.6 & 3.5 & 75.0 & 14.2 & 5.3 \\
\hline & Average & 99.9 & 16.0 & 5.6 & 74.8 & 16.0 & 5.0 \\
\hline \multirow{2}{*}{$\begin{array}{c}\text { Spruce + } \\
\text { Birch }\end{array}$} & I 10B+AS+P / II 10S & 96.5 & 24.7 & 3.9 & 82.5 & 25.6 & 3.2 \\
\hline & Average & 96.5 & 24.7 & 3.9 & 82.5 & 25.6 & 3.2 \\
\hline \multicolumn{2}{|c|}{ Average across all sampling areas } & 112.0 & 16.0 & 7.0 & 94.9 & 18.2 & 5.5 \\
\hline \multicolumn{8}{|c|}{ Late coming-out phenological form } \\
\hline \multirow{10}{*}{ Spruce } & 9S1P & 36.9 & 10.8 & 3.4 & 56.8 & 16.8 & 3.4 \\
\hline & 9S1P & 65.5 & 10.8 & 6.1 & 45.1 & 7.3 & 6.2 \\
\hline & $8 \mathrm{~S} 2 \mathrm{P}$ & 56.1 & 14.5 & 3.9 & 39.1 & 11.7 & 3.4 \\
\hline & $10 \mathrm{~S}+\mathrm{P}$ & 40.4 & 13.2 & 3.1 & - & - & - \\
\hline & 8,7S1,1P0,1B0,1AS & 53.1 & 9.0 & 5.9 & 73.4 & 8.5 & 8.7 \\
\hline & 6,5S3,1P0,3AS0,1B & 50.8 & 9.2 & 5.5 & 42.4 & 9.6 & 4.4 \\
\hline & 9,1S0,9B+AL & 101.8 & 8.2 & 12.4 & 91.9 & 7.5 & 12.2 \\
\hline & 7,8S1,6P0,6B & 101.9 & 9.9 & 10.3 & 96.8 & 11.1 & 8.7 \\
\hline & $6,6 \mathrm{~S} 3,2 \mathrm{P} 0,2 \mathrm{~B}$ & 82.6 & 9.0 & 9.2 & 77.8 & 9.6 & 8.1 \\
\hline & Average & 74.3 & 10.4 & 7.6 & 65.4 & 10.3 & 6.9 \\
\hline \multirow{7}{*}{ Pine } & $10 \mathrm{P}$ & 170.0 & 15.0 & 11.3 & 56.0 & 18.0 & 3.1 \\
\hline & $10 \mathrm{P}$ & 164.0 & 22.0 & 7.5 & - & - & - \\
\hline & $10 \mathrm{P}$ & 188.7 & 14.0 & 13.5 & - & - & - \\
\hline & 7,8P1,3S0,9B & 85.4 & 17.0 & 5.0 & 59.8 & 12.9 & 4.6 \\
\hline & 5P2S2B1AS & 86.5 & 29.0 & 3.0 & 105.8 & 31.3 & 3.4 \\
\hline & 6P2S2B & 43.4 & 14.8 & 2.9 & 72.9 & 15.9 & 4.6 \\
\hline & Average & 123.0 & 18.6 & 7.2 & 73.6 & 19.5 & 3.9 \\
\hline \multirow{7}{*}{ Pine + Spruce } & I 10P / II 9S1B & 120.0 & 21.3 & 5.6 & 97.8 & 21.4 & 4.6 \\
\hline & I 10P / II 5S5B & 123.3 & 19.7 & 6.2 & 76.5 & 9.2 & 8.4 \\
\hline & 4,9S4,1P0,8AS0,2B & 30.4 & 13.7 & 2.2 & 38.0 & 20.0 & 1.9 \\
\hline & $5,4 \mathrm{~S} 4,2 \mathrm{P} 0,4 \mathrm{AS}+\mathrm{B}$ & 44.6 & 11.8 & 3.8 & 36.6 & 10.7 & 3.4 \\
\hline & I 10P / II 7S2B1AS & 69.0 & 19.0 & 3.6 & 80.4 & 19.3 & 4.2 \\
\hline & 4P4S2B & 40.6 & 9.7 & 4.2 & 65.2 & 14.3 & 4.5 \\
\hline & Average & 1.3 & 15.9 & 4.3 & 65.8 & 15.8 & 4.5 \\
\hline \multirow{2}{*}{$\begin{array}{c}\text { Spruce + } \\
\text { Birch }\end{array}$} & I 10B+AS+P / II 10S & 68.5 & 19.6 & 3.5 & 60.0 & 22.5 & 2.7 \\
\hline & Average & 68.5 & 19.6 & 3.5 & 60.0 & 22.5 & 2.7 \\
\hline \multicolumn{2}{|c|}{ Average across all sampling areas } & 86.0 & 14.4 & 6.4 & 67.0 & 14.6 & 5.3 \\
\hline
\end{tabular}

Note: "P" - pine; "S" - spruce; "B" - birch; "AS" - aspen; "AL" - alder; "I" - first level of the stand; "II" - second level of the stand.

\section{Conclusions}

1. In general, in investigated forest types in conditions of the Leningrad region, the spruce undergrowth of an early form has better indices of growth and development under the canopy of mother stand. Irrespective of the state of the undergrowth's viability, an increase in these indices goes from the late phenological form to the early one.
2. Being approximately at the same age, the specimens of an early phenological form are higher and have a greater average increment in height. An average increment of viable spruce undergrowth of an early form is greater by $20-30 \%$ than that of spruce undergrowth of transitional and late forms, and greater by $30-35 \%$ than that of inviable spruce undergrowth. 
3. Irrespective of the phenological structure and state, the spruce undergrowth's average increment decreases by a factor of 2 to 4 with an increase in its relative normality, age and growing stock. This is associated with a decrease in the degree of light intensity under the stand's canopy. With a comprehensive tending of forest, an average increment of spruce undergrowth of all phenological forms decreases by a factor of 1.5 to 2 .

4. Generally speaking, the canopy of spruce stands provides a greater average annual increment in height to spruce undergrowth, irrespective of its phenological structure, categories of size and the state of viability, than the canopy of pine, pinespruce and birch-spruce stands. The vaccinium forest type has the best characteristics of spruce undergrowth, irrespective of its phenological form.

5. When analyzing characteristics of the spruce undergrowth under the stand's canopy with due regard to the phenological and height structure as well as to the state of viability, it was revealed that, at the dominant average age of spruce undergrowth of a transitional form, the best indices of small and medium-sized undergrowth are with an early phenological form, while the best indices of large undergrowth are with a late phenological form.

\section{References}

1. Akakiev, F.I. (1960). Некоторые биологические особенности и лесохозяйственное значение фенологических форм ели: (Some biological features and the importance of forestry for the phenological forms of spruce) the author's abstract of the dissertation of the candidate of agricultural sciences Leningrad, 16 c. (in Russian).

2. Alekseev, V.I. (1974). Некоторые вопросы сезонного роста и развития подроста ели (Some questions about seasonal growth and development of spruce growth) Seasonal development of the nature of the European part of the USSR. - Moscow, 32-33. (in Russian).

3. Barton, B.M. (1988). Variation in the phenology of bud flushing in white and red spruce / Can. J. Forest Res., 18. n.3., 315-319.

4. Belyaeva, N.V. (2013). Закономерности изменения структуры и состояния молодого поколения ели в условиях интенсивного хозяйственного воздействия (The patterns of changes in the structure and condition of the young generation of spruce under conditions of intensive economic impact): the author's abstract of the dissertation of the doctor of agricultural sciences. St. Petersburg Forestry University, 43 c. (in Russian).

5. Golikov, A.M. (2007). Рост и формовая структура потомства ели европейской в зависимости от гетерозиготности деревьев и условий произрастания (Growth and forming structure of European spruce, depending on the heterozygosity of trees and growth conditions) Moscow, Forest Science Journal. 4, 51-58. (in Russian).

6. Gryazkin, A.V., \& Belyaeva, N.V. (2013). Структура фенологических форм молодого поколения ели в условиях Ленинградской области (Structure of phenological forms of the young generation of spruce in the conditions of the Leningrad region) News of higher educational institutions "Lesnoy zhurnal".2, 84-92. (in Russian).

7. Gryazkin, A.V. (1997). Patent No. 2084129, Russian Federation, IPC C 6 A 01 G 23/00. Способ учета подроста (A method of accounting regrowth). - № 94022328/13; Declared 10.06.94; Published on July 20, 1997, Bulletin № 20. (in Russian).

8. Holzer, K., \& Schultze, U. (1988). Die Abhangigkeit des Fiechtenaustriebes vom Fruhjahrsklima (Dependence of phenological forms on the spring climate) Osterr. Forstztg, 99. n5, 59-60. (in German).

9. Kharitonov, G.A. (1937). Развитие рано- и позднораспускающихся рас Picea excelsa в связи с условиями местопроизрастания (Development of early and late-breaking races Picea excelsa in connection with the growth conditions) Soviet botany.4, 90-95. (in Russian).

10. Krasnobaeva, S.Yu. (2013). Лучшие климатипы ели обыкновенной в географических культурах в республике Татарстан (The best climate types of common spruce in the geographical cultures in the Republic of Tatarsta) Voronezh, Lesotechnical Journal.2, 31-37. (in Russian).

11. Makarov, Yu.I., \& Druzhinin, F.N. (2013). Внутривидовой и возрастной полиморфизм ели европейской (Picea abies (L.) Karst) в условиях Вологодской области (Intraspecific and age-related polymorphism of European spruce (Picea abies (L.) Karst) in Vologda region) Voronezh, Lesotechnical Journal 4, 24-32. (in Russian).

12. Martynov, A.N., Sennov, S.N., \& Gryazkin, A.V. (1994). Естественное возобновление леса (Natural regeneration of the forest: text of lectures) St. Petersburg: Publishing house of St. Petersburg Forestry Academy, 42 c. (in Russian). 
13. Melnik, P.G., \& Savostin, S.M. (1995). Особенности сезонного роста экотипов ели в условиях Солнечногорского опытного лесхоза (Peculiarities of seasonal growth of spruce ecotypes in the conditions of the Solnechnogorsky experimental leshoz) Scientific works: Forest use and reproduction of forest resources. - Issue 280. - Moscow: Publishing house MGUL, 62-63. (in Russian).

14. Milenin, A.I., \& Arbuzov, A.I. (2011). Освещенность и естественное возобновление ели европейской в зоне лесов Клинско-Дмитровской возвышенности (Illumination and natural renewal of European spruce in the forest zone of the Klin-Dmitrov Upland) Lesotechnical Journal. 3, 58-61. (in Russian).

15. Milyutin, L.I. (1963). Формы ели Брянской области, их лесоводственное и хозяйственное значение (The forms of spruce of the Bryansk region, their silvicultural and economic significance): the author's abstract of the dissertation of the candidate of agricultural sciences. Krasnoyarsk. 20 c. (in Russian).

16. Münch, E. (1923). Die Knospenentfaltung der Fichte und Spätfrostgefahr (The bud development of spruce and late frost). Allge-meine Forst- und Jagdzeitung.11, 241-265. (in German).

17. Paltsev, A.M. (1986). Влияния географического происхождения семян ели на ее рост (Influence of geographical origin of spruce seeds on its growth) the author's abstract of the dissertation of the candidate of agricultural sciences, Moscow, 18 c. (in Russian).

18. Popov, V.Ya., Tuchin, P.V., Surso, M.V., \& Vasiliev, A.A. (1985). Рост и развитие форм ели на плантации семенного происхождения (Growth and development of spruce forms on the plantation of seed production) Report of the annual session on the results of scientific research for 1984. Archangelsk: Arkhangelsk Institute of Forestry. 31-32. (in Russian).

19. Rohmeder, E. (1952).Der jahreszeitliche Verlauf des Höhenwachstums früh- und spättreiben-der Fichten. Forstwissenschaftliches Centralblatt (The seasonal course of the height growth of early and late-seasoned spruce trees. Forest Science Centralblatt).1 /12, 368-372. (in German).

20. Rohmeder, E. (1963). Ergebnisse aus züchterischen Bearbeitung der Fichte in Bayern (Results from breeding of spruce in Bavaria). Forst- und Holzwirt,18. n5, 93-96. (in German).

21. Ronis, E.Ya., \& Veveris, A.L. (1964). О некоторых формах ели обыкновенной в лесах Латвийской CCP (On some forms of spruce in the forests of the Latvian SSR) Studies on the nature of tree species. Riga: Publishing House of the Academy of Sciences of Latvian SSR, 5-20. (in Russian).

22. Tarkhanov, S.N., \& Shchekalev, R.V. (2007). Эндогенная и внутривидовая изменчивость полигенных признаков Picea obovata Ledeb. $\times$ P. abies (L.) Karst. в бассейне Северной Двины при атмосферном загрязнении (Endogenous and intraspecific variability of polygenic features Picea obovata Ledeb. $\times$ P. abies (L.) Karst. in the Northern Dvina basin under atmospheric pollution) Bulletin of the MGUL Forest Bulletin.5, 125-131. (in Russian). 